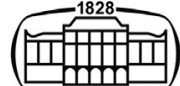

AKADÉMIAI KIADÓ

\title{
Examination of large-panel building apartments renovation
}

\author{
Olivér Rák $^{1 *} \odot$, Ágnes Borsos ${ }^{2}$ and Péter Iványi ${ }^{3}$
}

\section{Pollack Periodica \\ An International Journal \\ for Engineering and Information Sciences}

16 (2021) 2, 143-149

DOI:

10.1556/606.2021.00311

(c) 2021 The Author(s)

\author{
${ }^{1}$ Marcel Breuer Doctoral School of Architecture, Department of Engineering Studies, Institute of \\ Smart Technology and Engineering, Faculty of Engineering and Information Technology, University \\ of Pécs, Boszorkány u. 2, H-7624 Pécs, Hungary \\ ${ }^{2}$ Department of Interior, Applied and Creative Design Institute of Architecture, Faculty of \\ Engineering and Information Technology, University of Pécs, Boszorkány u. 2, H-7624 Pécs, Hungary \\ ${ }^{3}$ Department of Systems and Software Technologies, Faculty of Engineering and Information \\ Technology, University of Pécs, Boszorkány u. 2, H-7624 Pécs, Hungary
}

Received: December 2, 2020 • Revised manuscript received: February 23, 2021 • Accepted: March 19, 2021 Published online: April 23, 2021
ORIGINAL RESEARCH PAPER

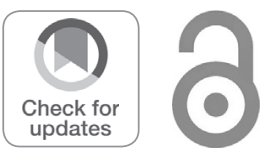

*Corresponding author.

E-mail: rak.oliver@mik.pte.hu

\section{ABSTRACT}

The increasing interest in large-panel building apartment renovation has heightened the need for a method-based examination. This research provides support to owners, investors, designers and habitants during decisions taking. The study covers the requirements, renovation trend, and cost evaluation. These criteria were defined by using general findings as the base of optimal renovations, which allows utilizing the results for wider areas. Renovations can be established to maintain or increase the value of apartments and the success of the investments depending on the optimal planning. The comfort needs, material selection, and the way of budget distribution are the main parameters of successful improvements. The analysis covers common quality renovation possibilities.

\section{KEYWORDS}

large-panel buildings, renovation, cost analysis, renovation value

\section{INTRODUCTION}

About 510,000 large-panel building apartments were built between 1961 and 1992 in Hungary [1]. Large number of these buildings has heightened the need for renovation support. In 2020, the structure of these buildings can function for more than 50-100 years [1] but nowadays the comfort level does not meet the requirements and trends. Interior renovations are also inevitable due to the obsolescence of the materials used. Damage to large-panel buildings is from physical abrasion and perceived devaluation [2] and in this research, the focus was on the physical part.

The property prices in Hungary has been rising to $172.5 \%$ in 2020 compared to 2015 [3]. Many enterprises have started to renovate apartments for selling purposes but their work is only focusing on the financial benefits. The present study provides support for owners, investors, designers and habitants on how to distribute the renovation budget and what methods can be applied to reach the higher value of a property.

The examined area was limited to the Garden City of Pécs. The reason is that previous researches have been established in this area, so there is existing information about largepanel buildings.

\section{MATERIALS AND METHODS}

Three main parts of the research can be distinguished that are related to an optimal renovation: definition of requirements, the budget optimization, and the support for decision 
making. These parts made it possible to have an overview of the market and to achieve the purpose of this study. In this research, the examined properties were collected from a website called "Ingatlan.com" [4]. There the location (streets), offer prices, and conditions were presented with related pictures. The information of 78 apartments was collected with different conditions with a wide range of price and location. These properties were used to do the analysis. As Fig. 1 represents the analysis was made by examining the needs, budget, and decision support possibilities. In the following paragraphs, these criteria have been examined separately.

\subsection{Definition of requirements}

In the case of the requirements the comfort, used material quality, and budget determination are relevant criteria. These are individual parameters related to personal expectations but those have to be defined before starting a renovation. Comfort is in rapport with the materials and the materials are in rapport with the budget. The owners usually know what they want, but they are confused about what possibilities they have. Large-panel buildings have been designed with simple spaces, but there is a lot of potential in them. The structural part is fixed and is not recommended to make significant changes, but the interior due to the schematic design can be variously modified [5]. The living space quality must meet the requirements of the owners, investors, designers or habitants according to the design trends. Other studies are focusing on these types of buildings' rehabilitation possibilities from the point of view of energy efficiency [6], structural [7], and comfort solutions [8], but the quality and the budget has also a huge effect on the renovation success. The large-panel building apartments are only parts of a multi-story building but those can have individual values. The value determination is important for the success of the renovation. The more money was spent the less benefit can be reached. The quality of materials and the budget determines how to renovate an apartment and what solutions can be applied. The renovation trend has to be examined to clarify and generalize the needs of the owners, investors, designers or habitants as a part of the requirements definition.

2.1.1. Examination of the renovation trend. Examination of trends was established by analyzing the collected renovated real estates. According to the description of advertisements and attached images the used materials were examined for different rooms. There were 27 renovated apartments examined.

In this research, the plan was to use real market prices but real estates were not able to provide selling prices and addresses because of the General Data Protection Regulation (GDPR) [9]. Realizing this issue, information was manually collected from the biggest Hungarian online real estate called "Ingatlan.com" [4]. There the prices have been offer prices and not selling ones, but the bargain of apartments may result in an average value, so this information was utilized.

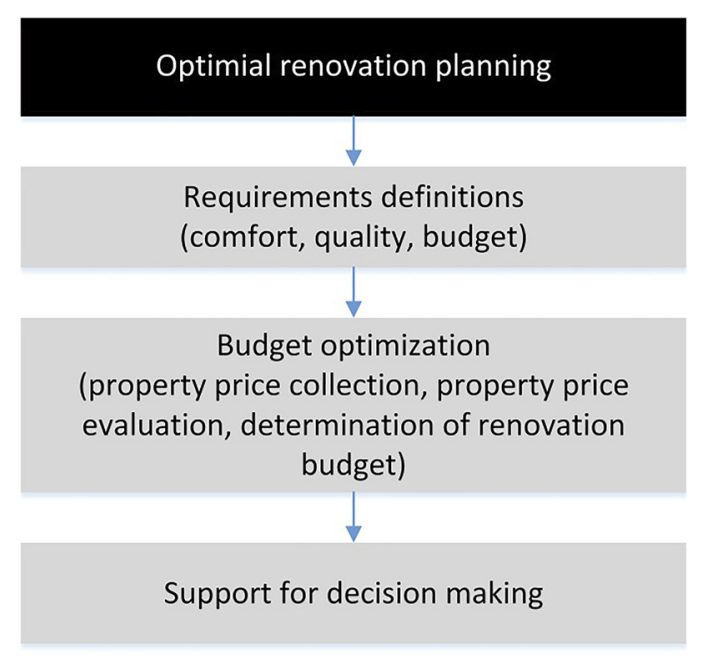

Fig. 1. The optimal renovation planning process

The data collection method was aligned with the main classification system and was used according to the conditions collected by the website. These conditions have been sorted by renovated, good, average, and need to be renovated conditions. 78 apartment prices were collected and an average price was calculated by the conditions. Then the location value was calculated to the properties as it was determined in a previous study [10]. Due to this method, the property prices were not distorted by their location and condition values and the clear apartment values could be calculated. The renovated apartments provided the base of the budget determination. So that the calculated average prices related to other conditions were subtracted from the renovated one to calculate the differences.

2.1.2. Renovation cost evaluation method. Calculating the renovation costs several criteria were examined due to the appraisers' recommendation. To determine the main factors of property value estimation in the case of large-panel buildings $[11,12]$ private interviews with professionals have been evaluated. They gave the information that the locations have enormous effects on prices and that is the reason why these values were calculated as it is presented in paragraph 3. The number, size, and type of rooms, floor plan design, entrance door, openings, electricity, heating, and condition of the radiators were examined during this study. Other criteria cannot be analyzed (e.g., building structure conditions, building security, usage of apartments in a building, etc.) generally because those are unique parameters however, those can affect the results. Therefore, the interior of the apartments was in focus. The source about real estate economics [13] describes the estimation of property, but in the case of large-panel building apartments, most of the criteria were not relevant due to their simplicity.

In a previous project, a story of a large-panel building geometry was surveyed by modern and traditional methods. The result of the survey was a Building Information Model (BIM model) $[14,15]$ what was used to calculate and manage the needed values. Lists were created in the model 
and then those were exported to an excel sheet. The cost calculation of the renovation was made by using offer and market prices according to the Hungarian cost estimate guide [16] what is supported by the Hungarian Government - Deputy Secretary of State for Architecture and Construction, Chamber of Hungarian Architects [17], Chamber of Hungarian Engineers [18], National Association of Construction Contractors [19], Budapest Chamber of Commerce and Industry [20]. This source was mainly used to estimate the cost of the occurring labor and materials. The purpose of the paper was to find optimal renovation possibilities, costs, and its dispersion by rooms as these have major impact on the renovation success.
2.1.3. Renovation decision support. The main objective of this study is to provide support to owners, investors, designers and habitants in the case of the renovation of an apartment which is located in a large-panel building. The previous paragraphs presented the criteria of decisions and the values that should be taken into account. During the support for decision making, these criteria must be assumed and a workflow shall be defined to reach the optimal renovation process. The way of thinking was described in Fig. 1 but the information has to be collected in a comparable format. Table 1 presents the form of the support and defines the main parameters, which have to be known in the case of renovations. The comfort levels are determined in

Table 1. Decision support chart for the optimal renovation determination

\begin{tabular}{|c|c|c|c|c|c|c|c|}
\hline \multirow{9}{*}{ 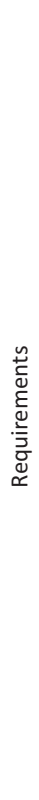 } & \multirow{4}{*}{$\begin{array}{l}\text { Comfort } \\
\text { criteria }\end{array}$} & Name of the room & Bathroom & Kitchen & $\begin{array}{l}\text { Living } \\
\text { room }\end{array}$ & Bedroom & Toilet \\
\hline & & $\begin{array}{r}\text { Number of rooms } \\
\text { (quantity) }\end{array}$ & 1 & 1 & 1 & 2 & 1 \\
\hline & & Min. size of rooms & $5 \mathrm{~m}^{2}$ & $10 \mathrm{~m}^{2}$ & $20 \mathrm{~m}^{2}$ & $10 \mathrm{~m}^{2}$ & $2 \mathrm{~m}^{2}$ \\
\hline & & Connected spaces & & \multicolumn{2}{|c|}{ In one space } & Separate & \\
\hline & \multirow{3}{*}{$\begin{array}{l}\text { Quality of } \\
\text { materials }\end{array}$} & \multirow{2}{*}{$\begin{array}{l}\text { Classification [23, } \\
24]\end{array}$} & PEI: 1 & PEI: 2 & $\underline{\text { PEI: } 3}$ & PEI: 4 & PEI: 5 \\
\hline & & & $\mathrm{AC} 21$ & \multicolumn{2}{|c|}{$\underline{\mathrm{AC} 22}$} & \multicolumn{2}{|c|}{ AC23 } \\
\hline & & Requirement & \multicolumn{5}{|c|}{$\begin{array}{l}\text { Average quality, tiles on floors in kitchen bathroom anc } \\
\text { toilet, laminated floor in living room and bedroom, tiles } \\
\text { on wall in kitchen and bathroom }\end{array}$} \\
\hline & \multirow[t]{2}{*}{$\begin{array}{l}\text { Quality of } \\
\text { equipment/ } \\
\text { furniture }\end{array}$} & $\begin{array}{r}\text { Classification [25] } \\
\text { (quality levels - } \\
\text { stability, strength, } \\
\text { durability, surface) }\end{array}$ & Moderate & Normal & $\underline{\text { Medium }}$ & Big & Special \\
\hline & & Requirement & \multicolumn{5}{|c|}{ Modern style } \\
\hline \multirow{5}{*}{ 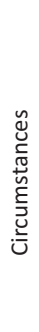 } & \multirow{5}{*}{ Budget } & Current condition & \multicolumn{5}{|c|}{ Needs to be renovated } \\
\hline & & Existing budget & \multicolumn{5}{|c|}{$2,500,000$ HUF } \\
\hline & & Calc. budget gap & \multicolumn{5}{|c|}{$78,223 \mathrm{HUF} / \mathrm{m}^{2}$} \\
\hline & & \multirow{2}{*}{ Budget dispersion } & Bathroom & \multicolumn{2}{|c|}{$\begin{array}{c}\text { Kitchen and living } \\
\text { room }\end{array}$} & Bedroom & Toilet \\
\hline & & & $20.09 \%$ & \multicolumn{2}{|c|}{$15.52 \%$} & $20.66 \%$ & $3.88 \%$ \\
\hline \multicolumn{8}{|c|}{ Decision support } \\
\hline \multirow{3}{*}{ 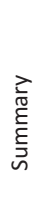 } & & $\Sigma$ : Size of rooms & $5 \mathrm{~m}^{2}$ & \multicolumn{2}{|c|}{$30 \mathrm{~m}^{2}$} & $20 \mathrm{~m}^{2}$ & $2 \mathrm{~m}^{2}$ \\
\hline & & $\begin{array}{l}\sum: \text { Renovation costs } \\
\text { by rooms }\end{array}$ & $\begin{array}{c}817,180 \\
\text { HUF }\end{array}$ & \multicolumn{2}{|c|}{631,290 HUF } & $\begin{array}{c}840,365 \\
\text { HUF }\end{array}$ & $\begin{array}{c}157,822 \\
\text { HUF }\end{array}$ \\
\hline & & $\sum$ : Budget gap & \multicolumn{5}{|c|}{$2,500,000$ HUF $-2,446,657$ HUF $=53,343$ HUF $\checkmark$} \\
\hline \multirow{3}{*}{ 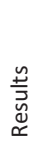 } & \multirow{3}{*}{$\begin{array}{c}\text { Renovation } \\
\text { success }\end{array}$} & Comfort scale & -2 & -1 & $\underline{0}$ & +1 & +2 \\
\hline & & Quality scale & -5 & -3 & $\underline{0}$ & +3 & +5 \\
\hline & & Budget scale & -2 & -1 & $\underline{0}$ & +1 & +2 \\
\hline
\end{tabular}


Table 2. Definition of the materials used during the renovation

\begin{tabular}{|c|c|c|c|c|}
\hline Rooms & Surface & Used materials & Summary of the percent of use & Comments \\
\hline \multirow[t]{2}{*}{ Entrance/Corridor } & Floor & Tile & $95.7 \%$ & \\
\hline & Wall & Paint & $91.3 \%$ & \\
\hline \multirow[t]{2}{*}{ Dining room } & Floor & Tile & $100.0 \%$ & $80 \%$ paint; $20 \%$ tile \\
\hline & Wall & Tile/paint & $87.0 \%$ & \\
\hline \multirow[t]{2}{*}{ Kitchen } & Floor & Tile & $100.0 \%$ & $80 \%$ paint; $20 \%$ tile \\
\hline & Wall & Tile/paint & $95.7 \%$ & \\
\hline \multirow[t]{2}{*}{ Bathroom } & Floor & Tile & $100.0 \%$ & \\
\hline & Wall & Tile/paint & $91.3 \%$ & $80.77 \%$ tile; $19.23 \%$ paint \\
\hline \multirow[t]{2}{*}{ Toilet } & Floor & Tile & $100.0 \%$ & \\
\hline & Wall & Tile/paint & $82.6 \%$ & $69.23 \%$ tile; $30.77 \%$ paint \\
\hline \multirow[t]{2}{*}{ Bedroom } & Floor & Laminated & $100.0 \%$ & \\
\hline & Wall & Paint & $95.7 \%$ & \\
\hline \multirow[t]{2}{*}{ Living room } & Floor & Laminated & $95.7 \%$ & \\
\hline & Wall & Paint & $82.6 \%$ & \\
\hline \multirow[t]{2}{*}{ Terrace } & Floor & Tile & $90.0 \%$ & \\
\hline & Wall & Paint & $100.0 \%$ & \\
\hline
\end{tabular}

government decree in Hungary [21] but the definitions they used are only related to the size, utilities, and heating system. In Baranya county, $42.7 \%$ of all flats were all-comfort in 2007 and this value is increasing [22]. Most of the largepanel buildings have all-comfort apartments, but the quality of the spaces is different. It is mainly related to the quality of materials used during the renovation. The strength of the coverings is mainly rated by the Porcelain Enamel Institute (PEI) value, which indicates how resistant is the material against damage resulted by daily usage [23]. Quite the same form of classification is available for laminated floors, which is named Abrasion Classes (ACs) [24]. The values, which were presented in Table 1 can be utilized for domestic usage. These are related to the required longevity of the renovated structures. If a room has to function for 20 years, it is recommended to use higher quality materials. In this study, a 10-year perspective was taken into account because the electrical, mechanical, and heating systems usually have to be renovated in 10 years. The furnishing [25] is also a part of the renovation but the choice of furniture is often based on mostly subjective regards. Table 1 contains information about it, but during the calculations, it is not counted because of its complexity (e.g., style, colors, sizes, qualities, spaces, etc.).

The second part of Table 1 represents a summary and results of the current renovation. The renovation success can be evaluated in numbers that are compared to the examined trends. The symbol 0 is the value when the renovation is totally aligned with the examined trends, -1 and -3 belong to lower, and -2 and -5 mean the lowest comfort, quality, or budget that was used for the renovation. Symbols +1 and +3 are related to higher, and +2 and +5 the highest comfort, quality, and budget level that can be planned for the renovation. These values can help to modify and optimize the parts of the renovation. The calculation in this study represents a trend-based renovation. As it was mentioned previously the requirements can be various and according to the needs, the optimized solution can be different. The scale values can be automatically calculated: in the case of comfort level, if the owner, investor, or user wants an extra room (e.g., bathroom) to be on the 'normal' comfort level, this value will increase to +1 . The quality scale depends on three different values (materials as ceramic and laminated floor, and equipment/furniture) so that if the PEI value is 5, AC23 is selected for laminated floor quality, and special furniture is chosen, the highest value will result in +5 .

In the case of the budget scale, the level 0 is the budget that was calculated in this study and the deviation of the budget will result in the value increasing or decreasing in Table 1.

\section{RESULTS AND DISCUSSION}

In paragraph 2.1.1 the renovation trend was highlighted as part of the optimization process and it provides the fundamental information (e.g., materials, spaces, costs) for the decision support.

Table 2 presents that the trend can be defined with more than $80 \%$ accuracy of what materials have been used for renovation of apartments nowadays. Some comments were added which indicate the ratio of different materials used in the same room. These were used during the calculation of renovation costs.

After the trend examination, the calculation of the renovation budget was established by using the renovated condition as fundamental information. Table 3 presents the results of the calculation what was created by using offer prices. After the location value was removed from the equation as was mentioned in paragraph 2.1.2. It presents the budget in the case of known conditions that are for example 66.697 HUF/ $\mathrm{m}^{2}$ for average condition apartments. This value shows that spending more money would increase the renovation costs to a level where the price margin would be too low.

If only the financial aspects of a project are considered it is visible that the feasibility of a higher investment will 
Table 3. Renovation budget calculation in the case of offer prices and the case of reduced prices by location values

\begin{tabular}{lcccc}
\hline Conditions & $\begin{array}{c}\text { Renovated } \\
\left(\mathrm{HUF} / \mathrm{m}^{2}\right)\end{array}$ & $\begin{array}{c}\text { Good condition } \\
\left(\mathrm{HUF} / \mathrm{m}^{2}\right)\end{array}$ & $\begin{array}{c}\text { Average condition } \\
\left(\mathrm{HUF} / \mathrm{m}^{2}\right)\end{array}$ & $\begin{array}{c}\text { Need to be renovated } \\
\left(\mathrm{HUF} / \mathrm{m}^{2}\right)\end{array}$ \\
\hline & 344,042 & Average prices of properties \\
Renovation budget & - & 318,197 & 281,451 & 274,820 \\
& & 25,845 & 62,591 & 69,222 \\
& 299,370 & Reduced average prices by location value & 221,147 \\
Renovation budget & - & 263,540 & 232,673 & 78,223 \\
\hline
\end{tabular}

depend on expectations of the owners, investors, designers, or habitants. The budget has the highest effect on the success of the renovation and it usually relates to the comfort and material quality. The requirements were defined according to the examined trends. To calculate the optimal renovation budget the quantities, works, and materials have to be taken into account.

After the quantities have been calculated the related budgets needed to be defined. The previously introduced system was used and as the result of the calculation, the costs of full renovation were calculated for three apartments. In most of the cases two prices were used for the calculation because the cost estimate guide [16] has contained a minimum and maximum pair of prices. Many criteria could distort the prices (e.g., using a higher quality of materials or if there is a need for special equipment during the renovation, etc.) but an average can be calculated, which can support decisions. After the renovation costs with minimum and maximum values were calculated their averages were examined by rooms. The windows, electrical renovation, and coverings of rooms were also counted but have separate values. It is because the rooms can be renovated separately but windows and electrical systems are recommended to at the same time in whole apartment. In the case of partial renovation, evidentially the costs per rooms could be higher whereas if the works were synchronized the renovation could cost less. Table 4 represents an example part of the calculation where the floors, ceilings and some wall covering workflows have been examined.

The calculated total price of the renovation is higher than the possible rise of the property value. It may be because of the high material and labor costs. In the last few years, the material prices increased more than $15-25 \%$ annually in the construction industry in Hungary $[26,27]$ but the property prices could not follow this high tendency. That is the reason why it is important to support decisions and clarify how much it cost to renovate the different parts of a property.

Table 5 presents the final ratio of the renovation costs between different rooms, openings, and electrical refurbishment. The diagram shows that the electrical renovation requires a high amount $(28.43 \%)$ of the total costs and the bathroom is also relevant with its $20.09 \%$.

The decision support chart can be used to determine which part of the property needs to be renovated and which parts are over the budget. Unfortunately, if the budget is over the limit or the required price margin cannot be reached the comfort or quality requirements should be lowered. The optimization process can contain different options for rooms (e.g., using different quality of laminated floor in bedroom and living room) or expected comfort that is also related to rooms (e.g., number of bathrooms - double comfort is not necessary).

Table 4. Example of the calculation of renovation costs

\begin{tabular}{|c|c|c|c|c|c|c|}
\hline & & & \multicolumn{2}{|c|}{ Floor covering } & \multicolumn{2}{|c|}{$\begin{array}{l}\text { Wall and ceiling } \\
\text { covering }\end{array}$} \\
\hline \multicolumn{3}{|c|}{ Refurbishment works } & \multicolumn{2}{|c|}{ Laminated floor } & \multicolumn{2}{|c|}{ Preparation } \\
\hline Unit & & & \multicolumn{2}{|c|}{$\mathrm{m}^{2}$} & \multicolumn{2}{|c|}{$\mathrm{m}^{2}$} \\
\hline Source of informat & & & \multicolumn{2}{|c|}{ III/1-8.2.1.3 [16] } & \multicolumn{2}{|c|}{ III/1-13.1.1.3 [16] } \\
\hline \multicolumn{3}{|c|}{ Cost/Unit $\left(\mathrm{HUF} / \mathrm{m}^{2}\right)$} & \multirow{2}{*}{7,500} & \multirow{2}{*}{11,000} & \multirow{2}{*}{1,200} & \multirow{2}{*}{1,800} \\
\hline Rooms & Area $\left(\mathrm{m}^{2}\right)$ & Wall surfaces $\left(\mathrm{m}^{2}\right)$ & & & & \\
\hline Entrance/Corridor & 9.46 & 28.18 & & & 33,816 & 50,724 \\
\hline Dining room & 7.44 & 25.54 & & & 30,648 & 45,972 \\
\hline \multicolumn{7}{|l|}{ Kitchen } \\
\hline Bathroom & 3.11 & 17.7 & & & & \\
\hline Toilet & 0.83 & 8.26 & & & & \\
\hline Bedroom & 18.9 & 51.8 & 141,750 & 207,900 & 62,160 & 93,240 \\
\hline Living room & 18.2 & 36.12 & 136,500 & 200,200 & 43,344 & 65,016 \\
\hline Terrace & 3.25 & 6.53 & & & 7,836 & 11,754 \\
\hline
\end{tabular}


Table 5. Ratio of renovation costs in the case of large-panel building apartments

\begin{tabular}{lc}
\hline Rooms & Ratio of renovation costs \\
\hline Entrance/corridor & $4.06 \%$ \\
Dining room/kitchen & $8.59 \%$ \\
Bathroom & $20.09 \%$ \\
Toilet & $3.88 \%$ \\
Bedroom & $10.33 \%$ \\
Living room & $6.93 \%$ \\
Terrace & $0.82 \%$ \\
Doors & $10.74 \%$ \\
Windows & $6.14 \%$ \\
Electrical & $28.43 \%$ \\
\hline
\end{tabular}

\section{CONCLUSION}

As a conclusion, this analysis can support the decisions on renovations. Although in this study large-panel building apartments from the Garden City of Pécs were examined but the results can be interpreted to other areas and types of buildings with similar forms. Examination of how the comfort, quality and budget were selected and distributed between rooms or the starting point of a renovation was supported by the ratio of the costs can be implemented for different projects. In some cases, renovation costs are higher than its effect on the property value and sometimes these are equal with the values related to their conditions. In the case of renovation, it is important to know accurately the initial conditions and define the optimal level of comfort, quality and budget, because the results can be vary. The findings of this study can be used as guidance for planning renovation and according to these results a complex program can be developed to solve the issues of the large-panel buildings on a country level.

\section{ACKNOWLEDGEMENTS}

This research had not been accomplished without the contribution of the Pécs Garden City Housing Association and the Building Information Modeling SKILLS (BIM SKILL LAB) research group. Special thanks to Frigyes Reinodli and the OTP Jelzálogbank Zrt. for the estimation support and to Gábor Babics for professional support in the case of openings.

\section{REFERENCES}

[1] A. Dési, Panel Guide. Építésügyi Tájékoztató Központ (in Hungarian), 1996.

[2] P. Birghoffer and L. Hikisch, Eds. Renovation of Prefabricated Residential Buildings. Budapest: Müszaki Könyvkiadó (in Hungarian), 1994.

[3] Housing market prices, housing price index 2020, I. quarter (in Hungarian). [Online]. Available: https://www.ksh.hu/docs/hun/ xftp/stattukor/lakaspiacar/20201/index.html. Accessed: Nov. 10, 2020.

[4] It's good everywhere, but the best is waiting for you here (in Hungarian). [Online]. Available: https://ingatlan.com. Accessed: Nov. 10, 2020

[5] B. Kokas, J. Balogh, A. Borsos, G. Medvegy, and B. Bachmann, "Harmonization of structural and functional lifespans of prefabricated residential buildings", Int. J. Des. Nat. Ecodynamics, vol. 15, no. 2, pp. 161-165, 2020.

[6] A. Horkai, B. Nemethi, and A. Talamon, "Smart solutions and opportunities for district heating: The case of Budapest", Interdiscip. Descr. Complex Syst., vol. 17, no. 1, pp. 78-84, 2019.

[7] W. Ligęza, "Renovation of large-panel buildings in context of urban renewal”, Civil Environ. Eng. Rep., vol. 17, no. 2, pp. 83-95, 2015.

[8] Á. Borsos, "Living spaces- prefabricated apartments", Pollack Period., vol. 9, no. 2, pp. 59-66, 2014.

[9] O. Radley-Gardner, H. Beale, and R. Zimmermann, Eds. Fundamental Texts On European Private Law. UK: Hart Publishing, 2016.

[10] O. Rák, Á. Borsos, and P. Iványi. “Algorithm-based BIM model analysis methodology at urban level”, in 7th International Academic Conference on Places and Technologies, Belgrade, Serbia, Oct. 29, 2020, 2020, pp. 305-312.

[11] "Interview about property value estimation criteria", Private Information, OTP Jelzálogbank Zrt, Nov. 24 (in Hungarian), 2020.

[12] R. Frigyes. "Interview about property value estimation criteria", Private Information, Nov. 02 (in Hungarian), 2020.

[13] J. Soós and D. Faust, Real Estate Economic. Budapest: KJK-Kerszöv (in Hungarian), 2002.

[14] Z. Márk and S. Beatrix, Bim-Manual-1.2-Terms-and-Definitions, vol. 1, Budapest, Lechner Nonprofit Kft, 2019.

[15] T. Mandičák, P. Mesároš, and M. Tkáč, "Impact of management decisions based on managerial competencies and skills developed through BIM technology on performance of construction enterprises", Pollack Period., vol. 13, no. 3, pp. 131-140, 2018.

[16] Construction Cost Estimating Guide 2020. Budapest: Hunginvest Mérnökiroda Kft (in Hungarian), 2020.

[17] Chamber of Hungarian Architects (in Hungarian). [Online]. Available: http://mek.hu/index.php?n=english. Accessed: Dec. 20, 2020.

[18] Chamber of Hungarian Engineers (in Hungarian). [Online]. Available: https://www.mmk.hu/. Accessed: Dec. 20, 2020.

[19] Hungarian Chamber of Engineers (in Hungarian). [Online]. Available: https://www.evosz.hu/. Accessed: Dec. 20, 2020.

[20] Budapest Chamber of Commerce and Industry (in Hungarian), [Online]. Available: https://bkik.hu/hu. Accessed: Dec. 20, 2020.

[21] 147/1992. (XI. 6.) Government Decree on the registration and reporting system of real estate owned by local governments Collection of legislation in force (in Hungarian). [Online]. Available: https://net.jogtar.hu/jogszabaly?docid=99200147. kor. Accessed: Dec. 20, 2020.

[22] 2.8. Distribution of apartments according to comfort level (in Hungarian). [Online]. Available: https://www.ksh.hu/docs/hun/ xtabla/onking/tablonk07_02_08.html. Accessed: Dec. 20, 2020.

[23] Ceramic knowledgebase. [Online]. Available: http://www. zalakeramia.hu/upload/files/katalogus/kisokos_2019/Kisokos_ 2019_08_22.pdf. Accessed: Dec. 20, 2020. 
[24] BS EN 13329:2016+A1:2017, Laminate floor coverings. [Online]. Available: https://shop.bsigroup.com/ProductDetail? pid $=000000000030350274$. Accessed: Dec. 27, 2020.

[25] MSZ 8865:1987, Qualification of furniture, 1987. [Online]. Available: https://ugyintezes.mszt.hu/Publications/Details/ 062031. Accessed: Dec. 27, 2020.
[26] G. Hegedüs, "Why is the Hungarian construction industry expensive?” (in Hungarian). [Online]. Available: https:// magyarepitok.hu/aktualis/2019/07/miert-draga-a-magyarepitoipar. Accessed: Nov. 10, 2020.

[27] Hungarian Central Statistical Office (in Hungarian). [Online]. Available: https://www.ksh.hu/arak. Accessed: Nov. 10, 2020.

Open Access. This is an open-access article distributed under the terms of the Creative Commons Attribution 4.0 International License (https://creativecommons.org/ licenses/by/4.0/), which permits unrestricted use, distribution, and reproduction in any medium, provided the original author and source are credited, a link to the CC License is provided, and changes - if any - are indicated. (SID_1) 